The Great Apes 


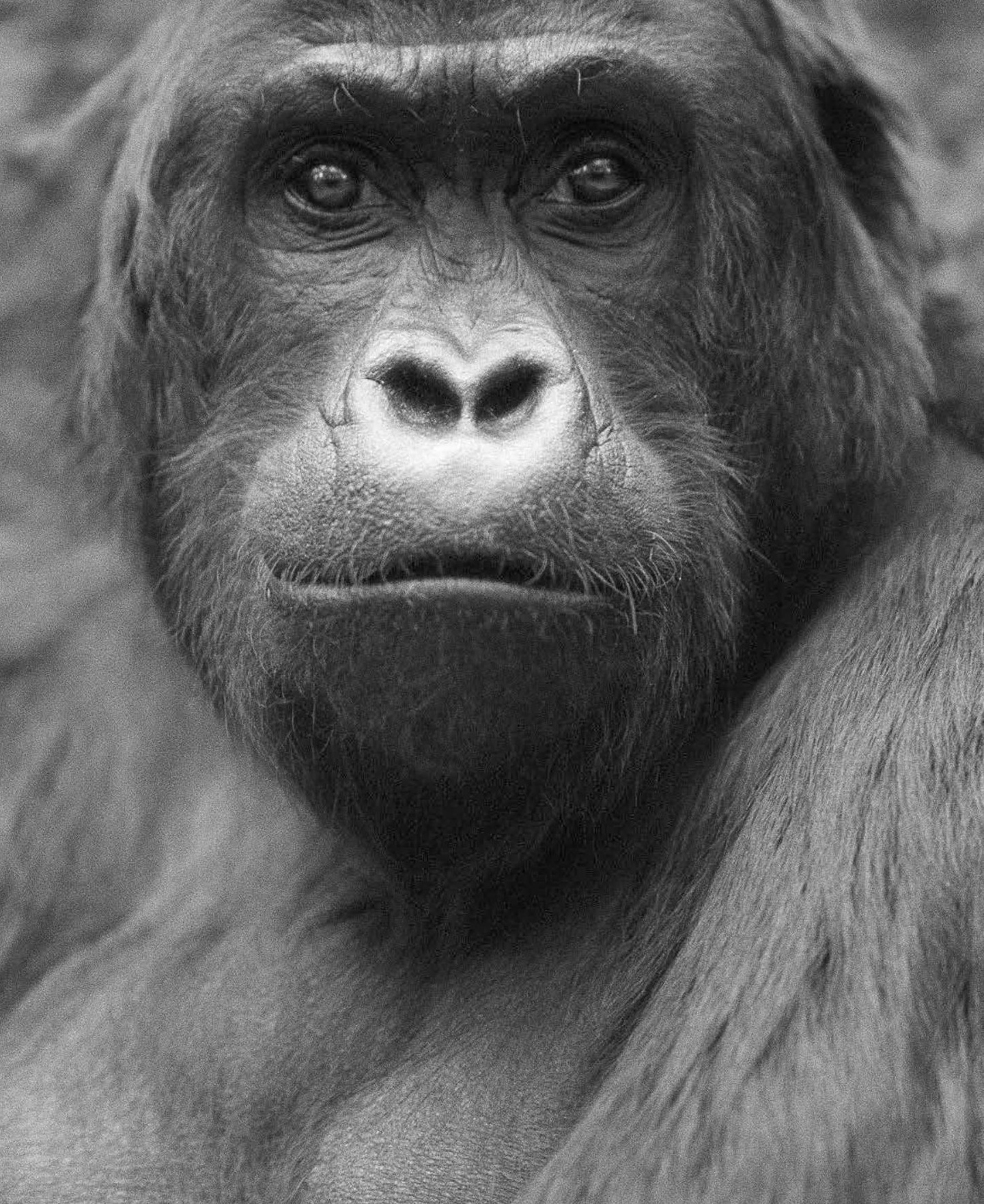




\title{
The Great Apes A Short History
}

\author{
Chris Herzfeld
}

Translated by Kevin Frey

FOREWORD BY JANE GOODALL

Yale

UNIVERSITY PRESS

New Haven \& London 
English translation copyright (C) 2017 by Kevin Frey.

Originally published as Petite histoire des grands singes. (C) Editions du Seuil, 2012.

All rights reserved.

This book may not be reproduced, in whole or in part, including illustrations, in any form (beyond that copying permitted by Sections 107 and 108 of the U.S. Copyright Law and except by reviewers for the public press), without written permission from the publishers.

Yale University Press books may be purchased in quantity for educational, business, or promotional use. For information, please e-mail sales.press@yale.edu (U.S. office) or sales@yaleup.co.uk (U.K. office).

Set in Bulmer type by Newgen North America, Austin, Texas.

Printed in the United States of America.

ISBN 978-0-300-22137-4 (hardcover : alk. paper)

Library of Congress Control Number: 2017940993

A catalogue record for this book is available from the British Library.

This paper meets the requirements of ANSI/NISO Z39.48-1992 (Permanence of Paper).

10987654321

Frontispiece: Victoria (June 9, 1968-May 21, 2016), Antwerp Zoo, 1996.

(This portrait appears in the book Les grands singes: L'humanité au fond des yeux, by Pascal Picq, Dominique Lestel, Vinciane Despret, and Chris Herzfeld [Editions Odile Jacob, 2005], (C) Editions Odile Jacob/Chris Herzfeld, MNHN, 2005) 